\title{
MODEL PEMAKNAAN NASIONALISME MASYARAKAT PULAU SEBATIK KALIMANTAN TIMUR ${ }^{1}$
}

\author{
Muhammad Hairul Saleh \\ Staf Pengajar Fisip Universitas Mulawarman \\ Jl. Gunung Kelua, Samarinda
}

\begin{abstract}
This study is aimed to know the understanding models of Sebatik Island's people about nationalism. Using phenomenological approach, the result of this study indicates that there are three models of society understanding about nationalism. They are the understanding by society who have Identity Card of Indonesia (established people), understanding by society who have Identity Card both Indonesia and Malaysia or double citizenship, and nationalism understanding of society being Malaysia citizen (Malaysian loves Indonesia). The first and the second models are elaborated based on some indicators, such as ownership of identity card, currency, economics, language, education, political participation, celebration of Republic of Indonesia's independence day, and Ambalat case; and the third model is a description to complete the first and the second models explanation.
\end{abstract}

Keywords : understanding, nationalism, society of Sebatik Island, Indonesia-Malaysia border.

\section{Intisari}

Penelitian ini bertujuan untuk mengetahui model pemaknaan masyarakat Pulau Sebatik terhadap nasionalisme. Dengan menggunakan pendekatan fenomenologik, hasil penelitian menunjukkan terdapat tiga model pemaknaan masyarakat terhadap nasionalisme, yakni pemaknaan oleh masyarakat yang hanya memiliki KTP Indonesia (orang tempatan), pemaknaan oleh masyarakat yang memiliki KTP Indonesia dan ID Card Malaysia atau berkewarganegaraan ganda, dan pemaknaan nasionalisme masyarakat yang telah menjadi warga negara Malaysia (orang Malaysia yang cinta Indonesia). Model pertama dan kedua dielaborasi berdasarkan beberapa indikator, seperti kepemilikan KTP, mata uang, ekonomi, bahasa, pendidikan, partisipasi politik, perayaan HUT kemerdekaan RI, dan kasus Ambalat, sedangkan model ketiga hanya berupa penggambaran

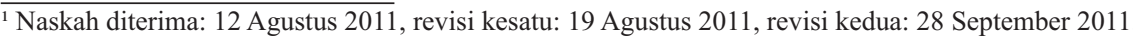


untuk melengkapi menjelasan model pertama dan kedua.

Kata kunci : pemaknaan, nasionalisme, masyarakat Pulau Sebatik, perbatasan Indonesia-Malaysia

\section{A. PENDAHULUAN}

Pulau Sebatik merupakan satu dari 12 pulau terluar dalam wilayah NKRI yang berbatasan langsung dengan negara tetangga. Sebagai pulau kecil di wilayah perbatasan IndonesiaMalaysia, Pulau Sebatik memiliki peran yang strategis sebagai beranda depan Indonesia dalam menjaga kedaulatan NKRI. Terdapat dua implikasi yang dapat dilihat dari posisi Pulau Sebatik tersebut, secara positif dapat dimanfaatkan untuk menciptakan kesejahteraan pada masyarakat Pulau Sebatik karena tingginya interaksi antara masyarakat Pulau Sebatik dengan masyarakat Malaysia. Bagi masyarakat Pulau Sebatik tentunya menjadi peluang bisnis yang dapat manfaatkan semaksimal mungkin.

Di sisi lain, dengan adanya perdagangan global dapat berdampak negatif, khususnya terhadap rasa nasionalisme di tengah tingginya interaksi antar masyarakat di perbatasan negara. Nasionalisme kemudian menjadi isu yang sangat krusial karena menyangkut pertarungan harga diri bangsa di hadapan bangsa lain. Mengapa isu tentang nasionalisme di Pulau Sebatik menjadi sangat penting dalam penelitian ini? Pertama, masyarakat Pulau Sebatik memiliki ketergantungan yang sangat kuat pada Tawau-Malaysia dari sisi ekonomi yang menyebabkan mobilitas masyarakat lebih banyak ke Tawau ketimbang ke Nunukan.
Kedua, Pulau Sebatik memiliki ketertinggalan di berbagai sektor, seperti ekonomi, sosial, politik, infra struktur, serta keterbatasan kemampuan sumberdaya manusia (SDM) dari segi kualitas maupun kuantitas dibandingkan dengan masyarakat di wilayah lain. Ketiga, pemerintah pusat dan daerah sepertinya belum serius melakukan pembangunan di desa ini. Hal ini kemudian memunculkan kekuatiran dari berbagai kalangan yang menilai bahwa nasionalisme masyarakat di perbatasan mulai memudar seiring dengan adanya kesenjangan antara masyarakat perbatasan Indonesia dengan masyarakat perbatasan negara tetangga. Berangkat dari uraian tersebut, maka tulisan ini bermaksud untuk menguak tabir nasionalisme masyarakat Pulau Sebatik Kalimantan Timurdi tengah kondisi yang melingkupinya.

Fakta menunjukkan bahwa Pulau Sebatik yang berada di perbatasan Indonesia-Malaysia selama ini memang belum tersentuh pembangunan yang maksimal. Meskipun belakangan ini, pemerintah telah melakukan transformasi wacana kawasan perbatasan yang bukan lagi memandang kawasan perbatasan sebagai halaman "belakang", tapi halaman "depan", pulau-pulau yang ada di perbatasan bukan lagi sebagai pulau "terluar", tapi pulau "terdepan" dalam bingkai NKRI, namun dalam kenyataannya, negara sepertinya 
belum memiliki komitmen yang serius untuk mengelola wilayah perbatasan.

Program pembangunan kawasan perbatasan yang diharapkan menyentuh seluruh aspek kehidupan masyarakat perbatasan tidak berjalan sebagaimana mestinya. Menurut peneliti P2P-Pusat Penelitian Politik LIPI, Ganewati Wuryandari, kebijakan dari berbagai instansi terkait dengan penanganan kawasan perbatasan selama ini belum sinkron, yang pada akhirnya berdampak bukan hanya pada sisi memboroskan anggaran negara, tetapi pemerintah juga seringkali mengabaikan dan melupakan keberadaan masyarakat lokal (Kompas, 17 Pebruari 2009).

Salah satu contoh masih kurangnya perhatian pemerintah dalam mengelola pulau-pulau kecil di wilayah perbatasan, khususnya di Pulau Sebatik adalah belum adanya ruas jalan besar yang cukup memadai sebagai infrastruktur pendukung peningkatan perekonomian masyarakat. Ruas jalan yang ada sekarang, menurut hemat penulis belum cukup mendukung bagi peningkatan roda perekonomian masyarakat. Fakta ini menurut Sriwidjoko (dalam Abubakar, 2006: 73), bahwa Pemerintah Indonesia masih berfikir keuntungan ekonomi seperti apa yang didapatkan kalau melakukan pembangunan di daerah dengan jumlah penduduk yang minim. Dengan pola pikir tersebut, maka tidak heran kalau sampai sekarang kondisi wilayah perbatasan dan pulau-pulau yang berbatasan langsung dengan Malaysia masih sangat tertinggal jika dibandingkan dengan wilayah Malaysia yang berada di perbatasan.
Kondisi ini sangat berbeda dengan wilayah perbatasan negara Malaysia, dimana kebijakan pemerintah Diraja Malaysia lebih memperioritaskan pembenahan garis perbatasan negaranya, tanpa berpikir apakah secara ekonomi layak atau tidak. Konsep pembangunan di Malaysia Timur tampaknya diarahkan pada perencanaan tata kota terlebih dahulu (Ratnawati, 2006: 105-106). Salah satunya dengan membangun jalan sepanjang garis perbatasan. Sebagai gambaran, sebelum memperoleh kemerdekaan dari pemerintahan Kerajaan Inggris program pembangunan Malaysia telah lebih dulu diciptakan. Rencana pembangunan Tanah Melayu 1950 (draft development plan of federation Malaya) yang dibuat oleh pemerintah Kerajaan Inggris adalah salah satu bukti bahwa Malaysia lebih dahulu memikirkan bagaimana memajukan rakyatnya. Secara menyeluruh rancangan itu berisi empat tujuan utama, yaitu 1) pembangunan pelayanan masyarakat, 2) pembangunan sumberdaya negara, 3) pembangunan perdagangan dan perindustrian, dan 4) rumusan tentang kemungkinan sumber keuangan negara untuk membiayai rancangan ini (Higgins, dalam Nasution, 2001:21).

Adanya perbedaan "perlakuan" antara pemerintah Indonesia dengan pemerintah Malaysia di wilayah perbatasan kedua negara ini, dikuatirkan akan menyebabkan hilangnya rasa kebangsaan masyarakat Pulau Sebatik terhadap Indonesia. Ketimpangan ekonomi akan menjadi pemicu tumbuhnya "kecemburuan sosial" yang dapat 
berbuah pada sikap antipati masyarakat terhadap Indonesia dan sebaliknya simpati terhadap Malaysia. Lebih parah lagi kalau pada akhirnya akumulasi dari kekecewaan masyarakat tersebut kemudian memunculkan keinginan masyarakat untuk berpindah kewarganegaraan menjadi warga negara Malaysia.

Ini sangat mungkin terjadi karena Pulau Sebatik yang berbatasan dengan Tawau-Malaysia, aktifitas ekonomi masyarakatnya sangat tergantung pada kondisi perekonomian Tawau. Apalagi dalam kehidupan sehari-hari masyarakat menggunakan dua mata uang yaitu ringgit dan rupiah, ringgit merupakan mata uang utama dan rupiah hanya menjadi mata uang "alternatif" saja. Kondisi ini telah berlangsung sejak lama, sehingga dapat dikatakan bahwa perekonomian pulau Sebatik dipengaruhi oleh kondisi ekonomi Malaysia bukan Indonesia. Tingkat kesejahteraan masyarakat sangat tergantung pada perputaran ekonomi Malaysia, khususnya Tawau karena mayoritas hasil pertanian masyarakat, seperti pisang, coklat dan lain-lain setiap harinya dipasarkan ke Tawau.

Masyarakat Pulau Sebatik lebih senang berbelanja ke Tawau ketimbang ke Nunukan mengingat jarak tempuhnya relatif lebih singkat. Sebagai gambaran, dari Pulau Sebatik ke Tawau misalnya, dengan jarak hanya 5 mil laut dapat ditempuh dalam waktu 15 menit menggunakan speedboat, sedangkan ke kota Nunukan ditempuh dengan waktu 2 jam. Secara ekonomis, tentu ini sangat menguntungkan mereka karena ongkos transportasi dapat dikurangi. Selain itu, mereka juga sudah terbiasa bertransaksi dengan menggunakan mata uang ringgit. Bahkan yang lebih utama karena harga barang-barang pokok (sembako) produk Malaysia sangat terjangkau oleh masyarakat Sebatik ketimbang harga barang-barang produk Indonesia.

Dengan kondisi ini, tidak salah kalau kemudian banyak masyarakat Pulau Sebatik menggantungkan hidup di Malaysia. Mereka lebih senang memburu ringgit ke Malaysia ketimbang memburu rupiah di Indonesia. Kesenangan mereka berburu ringgit bukan tanpa alasan. Salah satu alasan kuat yang mendasari adalah karena nilai ringgit lebih tinggi ketimbang rupiah. Lebih parah lagi, anak-anak ternyata sudah memahami hal, sehingga mereka lebih senang meminta ringgit kepada orang tua ketika membutuhkan sesuatu dari pada rupiah.

Dari realitas empirik seperti yang digambarkan di atas, maka pertanyaan yang akan dijawab dalam tulisan ini adalah; Bagaimana model pemaknaan masyarakat Pulau Sebatik terhadap nasionalisme?

Tulisan ini menggunakan pendekatan fenomenologi yang banyak digunakan oleh antropologi, mengingat fokus empiris kajian antropologi adalah kajian komunitas lokal, dan masyarakat Pulau Sebatik adalah sebuah komunitas masyarakat lokal di perbatasan. Menurut Ahimsa-Putra, fenomenologi sangat cocok digunakan untuk mengkaji hakekat makna yang ada dalam pengalaman dan tindakan 
manusia. Hakekat makna yang ada dalam pengalaman dan tindakan manusia menyebabkan pendekatan seperti yang dilakukan pada ilmu alam dalam ilmu sosial tidak lagi mengena, karena masalahnya berada pada tingkat yang berbeda, yakni tingkat makna. Dengan menggunakan pendekatan fenomenologi, penelitian ini mencoba mengungkapkan konstruksi masyarakat perbatasan antar negara terhadap nasionalisme, yang lebih memusatkan perhatian pada dimensi makna dan pengetahuan manusia (masyarakat) (Hamdanah, 2005: viii).

Tujuan penelitian ini berupaya memahami dan mengungkap fakta empirik mengenai pemaknaan nasionalisme masyarakat pinggiran di pulau Sebatik Kalimantan Timur ditengah kuatnya ketergantungan terhadap negara Malaysia. Manfaat penelitian dapat dibagi menjadi dua, yakni praktis dan akademis. Pada tataran praktis, kajian tentang nasionalisme masyarakat pinggiran di perbatasan negara memungkinkan kita untuk mengetahui adanya perbedaan pemaknaan antara masyarakat yang ada di perbatasan dengan pemerintah (negara) akan nasionalisme. Pada tataran akademis atau teoritis, hasil penelitian ini diharapkan menjadi sumbangan pemikiran dan referensi teoritis yang baru dalam melihat nasionalisme masyarakat pinggiran yang ada di perbatasan negara.

\section{B. TINJAUAN PUSTAKA \\ a. Konsep Nasionalisme}

Secara etimilogis, term nasionalisme, natie, dan national, kesemuanya berasal dari bahasa Latin, yakni nation, yang berarti bangsa yang dipersatukan karena kelahiran. Kata nation ini berasal dari kata nascie yang berarti dilahirkan (Moesa, 2007: 29). Monigue mendefinisikan nasionalisme sebagai gerakan politik yang berusaha untuk mencapai dan mempertahankan tujuan yang disebut integrasi nasional (1967: 25). Senada dengan Monigue, Mas'oed (2000), memberi definisi nasionalisme sebagai gerakan politik yang berusaha memperoleh dan menerapkan kekuasaan negara dan memberi pembenaran terhadap tindakan tersebut dengan argumen kepentingan nasional.

Anderson (1999:7) memberikan defenisi tentang nasion dengan menggunakan semangat antropologis bahwa "bangsa atau nasion adalah komunitas politik dan dibayangkan sebagai suatu yang bersifat terbatas secara inhern sekaligus berkedaulatan", dalam pengertian bangsa merupakan komunitas politik yang dibayangkan (an imagined political community) dalam wilayah yang jelas batasnya dan berdaulat. Kata imagined lebih berarti "orang-orang yang mendefeninsikan diri mereka sebagai anggota suatu nasion, meski mereka tidak mengenal, tak pernah bertemu, atau bahkan mendengar tentang warga negara lain, namun dalam pikiran mereka hidup sebagai suatu citra (image) mengenai kesatuan komunion bersama (Saifuddin, dalam Tjondronegoro, 2007:4). 
Dibayangkan secara terbatas karena bangsa yang paling besar sekalipun, yang penduduknya ratusan jiwa mempunyai batas wilayah yang relatif jelas. Dibayangkan berdaulat karena bangsa berada di bawah suatu negara mempunyai kekauasaan atas seluruh wilayah bangsa tersebut. Akhirnya disebut sebagai komunitas yang dibayangkan karena lepas dari kesenjangan dan penindasan, para anggota bangsa itu saling memandang satu sama lain sebagai saudara sebangsa dan setanah air (Surbakti, 2007: 42). Kartodirdjo (1999: 15$)$ mengemukakan bahwa, terdapat lima prinsip dalam nasionalisme, dimana yang satu dengan lainnya saling terkait untuk membentuk wawasan nasional. Kelima prinsip itu adalah kesatuan (unity), kemerdekaan/kebebasan (liberty), kesamaan (equality), kepribadian (personality), dan prestasi (performance).

Menurut Rauf (2008: 89) nasionalisme adalah penguatan faham kebangsaan, dan Saifuddin (2008: 5) mengemukakan bahwa nasionalisme tidak lain adalah rasa kebangsaan. Rasa kebangsaan yang berwujud rasa cinta tanah air dan bangsa dapat ditumbuhkan melalui penguatan faham kebangsaan. Menguatnya nilai-nilai kebangsaan pada akhirnya menjadi modal penting bagi terbentuknya keutuhan dan persatuan bangsa dan negara.

Dari sekian banyak definisi nasionalisme yang dikemukakan oleh para ahli dan akademisi, dalam penelitian ini penulis mengkombinasikan argumentasi yang diajukan oleh Rauf dan Saifuddin dengan asumsi bahwa dalam konteks nasionalisme masyarakat Indonesia, pandangan ahli lokal tentang nasionalisme menjadi sangat sesuai mengingat kondisi masyarakat Indonesia sangat jauh berbeda dengan masyarakat yang ada di Barat. Nasionalisme Indonesia dengan faham kekeluargaannya jelas tidak akan sama dengan nasionalisme B a rat de ngan fah a m individualismenya. Apa yang dikemukakan oleh Rauf dan Saifuddin, menurut hemat penulis sangat cocok digunakan dalam melihat bagaimana pemaknaan nasionalisme masyarakat pinggiran yang ada di perbatasan. Rasa kebangsaan seperti apa yang dimaknai oleh masyarakat Pulau Sebatik ditengah ketergantungan ekonomi pada Malaysia?

\section{b. Berbagai Perspektif Tentang Nasionalisme \\ Pada bagian ini akan disajikan} beberapa tinjauan hasil-hasil penelitian terdahulu yang secara teoritis berkaitan dengan fokus penelitian ini. Penulis akan mengklasifikasikan sesuai dengan pendekatan yang digunakan oleh setiap ahli. Dalam pendekatan politik, penulis mengutip pendapat Mas'oed, Hara, Zakaria, dan Santoso. Mas'oed (2000), mengemukakan bahwa wacana nasionalisme berlangsung dalam dua aras, yakni aras idea (gagasan) 
dan struktural (kebijakan). Pada aras idea atau gagasan, nasionalisme dianalisis sebagai 'state of mind' atau sebuah perwujudan kesadaran nasional dari para individu anggota suatu bangsa.

Pada aras struktural atau kebijakan, nasionalisme dipahami sebagai bentuk perpolitikan, suatu strategi politik. Dalam pengertian, nasionalisme merupakan bagian dari fenomena politik. Karena politik selalu berkaitan dengan persoalan pengendalian Negara, maka nasionalisme selalu berkenaan dengan bagaimana memperoleh dan menggunakan kekuasaan Negara. Dengan kata lain, nasionalisme didefinisikan sebagai gerakan politik yang berusaha memperoleh dan menerapkan kekuasaan Negara dan member pembenaran terhadap tindkan tersebut dengan argument kepentingan nasional (Moesa, 2007:30-31).

Hara (2005) melihat nasionalisme kaitannya dengan globalisasi. Dengan mengambil contoh kasus di Indonesia, Hara mengemukakan bahwa dominasi negara yang begitu lama terhadap masyarakat sipil menyebabkan nasionalisme menjadi tumpul dan kehilangan ruh kemanusiaan. Oleh karena itu, nasionalisme Indonesia haruslah nasionalisme yang kosmopolit, dimana peran negara dan nasionalisme mengalami transformasi, sehingga negara tidak lagi bisa mengklaim kedaulatan mutlak untuk mengatasi berbagai masalah. Negara harus bekerja sama dengan dunia internasional untuk memerangi ancaman global terhadap kemanusiaan, seperti kasus terorisme.

Zakaria (2006), mencoba menggali nasionalisme dengan memberi gambaran dialektika nasionalisme dalam pandangan Hegel. Menurutnya, pemikiran Hegel pada mulanya hanya merupakan gagasan yang ditarik atau diilhami dari penjelmaan Great Spirit dan Absolute Idea, kemudian berkembang menjadi negara dan paham nasionalisme di Jerman, Eropa dan wilayah-wilayah lain yang merupakan dialektika dari tesa, antitesa, dan sintesa yang terus berkembang (2006: 18). Santoso (2001), dalam tulisannya lebih memfokuskan pada kajian tentang nasionalisme, otonomi daerah dan demokratisasi kaitannya dengan merajut kohesi nasional. Ada dua nasionalisme Indonesia menurut Santoso, yaitu nasionalisme primer (alami) yang cakupannya adalah etnisitas dan nasionalisme sekunder (rakitan) yang cakupannya adalah supra etnis atau lintas etnis. Yang dominan dalam konteks nasionalisme Indonesia adalah nasionalisme sekunder karena adanya belaan dan perlindungan negara. Dalam hal ini kohesi nasional memiliki dua bahan utama, yakni kebersamaan dan kemajuan, jika salah satu atau kedua-duanya macet, maka keretakan kohesi nasional akan terjadi (2001: 268).

Dalam pendekatan Historis, ada dua yang penulis kutip, yakni pandangan Legawa dan Purwanto. 
Dengan mengambil contoh kasus Indonesia, Legawa (2007), mengkaji nasionalisme dengan mengupas nasionalisme negaranegara postkolonial yang menurutnya muncul sebagai sebuah bentuk perjuangan anti-kolonial yang merupakan ekspresi pemberontakan atas diskriminasi dan ketidakadilan selama kolonialisme yang dirasakan oleh subyek yang terjajah. Lebih lanjut Legawa menunjukkan bahwa nasionalisme postkolonial merupakan adopsi dari nilai-nilai Barat untuk bisa sejajar dengan peradaban Barat, namun di sisi lain terjadi penolakan atas Barat karena dampak kolonialisme yang ditimbulkan. Dalam hal ini terjadi proses hibridasi, dimana gabungan antara pembaratan dengan nilainilai spritual ketimuran menghasilkan sebuah identitas kebangsaan baru, yang walaupun meniru Barat, tapi tidak sepenuhnya Barat. Inilah kemudian yang disebut sebagai identitas nasional postkolonial.

Purwanto (2001), lebih memfokuskan kajian pada bagaimana memahami kembali nasionalisme Indonesia yang menurutnya sedang mengalami problematika disintegrasi, yang berawal dari munculnya konflik identitas kebangsaan dan etnisitas yang berdimensi banyak (2001: 250). Perlunya memahami kembali nasionalisme Indonesia dengan jalan merubah paradigma nasionalisme masa depan yang tidak lagi terikat pada perlawanan terhadap kolonialisme atau patriotisme dalam mempertahankan kemerdekaan, namun yang lebih penting adalah bagaimana memahami identitas keindonesiaan sesuai dengan perubahan yang terjadi. Oleh karenanya, secara historis perkembangan nasionalisme Indonesia harus dilihat lebih rasional dan obyektif sebagai sebuah proses.

Senada dengan perspektif Legawa dan Purwanto, akan disajikan pula pandangan ahli Barat. Ernest Gellner (1983), Hans Kohn (1969), dan Eric Hobsbaum, ketiganya mengaitkan eksistensi bangsa dengan "kesejarahan". Dalam pandangan mereka, nasionalisme adalah bagian dari budaya tinggi (high culture), dimana nasionalisme tidak bersifat ilmiah, tetapi merupakan suatu gejala sejarah yang timbul sebagai respon terhadap kondisi politik, ekonomi, dan sosia tertentul. Dari latar belakang sejarah seperti itulah nasionalisme dimaknai sebagai suatu perjuangan untuk membuat budaya dan politik selalu bersesuaian. Lebih tegas lagi dijelaskan bahwa nasionalisme adalah "pemaksaan umum" suatu budaya tinggi terhadap budaya yang paling rendah. Padahal budaya yang lebih rendah tersebut sebelumnya telah mengangkat kehidupan kelompok mayoritas (Moesa, 2007: xiii).

Nasionalisme mengandung makna sikap politik dan sosial dari kelompok-kelompok suatu bangsa yang mempunyai kesamaan kebudayaan, bahasa, dan wilayah, 
serta kesamaan cita-cita dan tujuan, yang dengan demikian merasakan adanya kesetiaan yang mendalam terhadap bangsa (Moesa, 2007: 29). Dalam konteks ini, kata kunci dalam nasionalisme adalah supreme loyality terhadap kelompok bangsa. Kesetiaan ini muncul karena adanya kesadaran akan identitas kolektif yang berbeda dengan yang lain.

$\mathrm{D}$ a 1 a m pende k a t a n Struktural, dikutip pandangan Moesa, Azra, Abdus Salam, dan Fahru-Munabari. Moesa (2007), dengan mengambil kasus Indonesia, mencoba mengkaji hubungan antara agama dengan nasionalisme. banyak pihak yang menilai bahwa agama bertentangan dengan nasionalisme, bahkan sering dianggap sebagai pengrusak keutuhan sebuah negara. Namun dari hasil penelitian ini, Moesa malah menemukan bukti yang justru terbalik, dimana menurut Moesa agama ternyata bisa menjadi faktor perekat bangsa (integrating force) dan sekaligus bisa menjadi basis ikatan solidaritas sosial yang kuat (supra identity) antar warga bangsa. Moesa menunjukkan bahwa agama (Islam) menjadi faktor penguat kesadaran pengalaman kesejarahan sebagai dasar terbentuknya negara-bangsa Indonesia (Moesa, 2007: xii).

Dalam konteks yang sama Azra mengemukakan bahwa dalam kasus Indonesia, Islam menjadi salah satu unsur genuine, pendorong munculnya nasionalisme Indonesia, setelah berhasil menjinakkan sentimen etnisitas untuk menumbuhkan loyalitas etnisitas lebih tinggi, yang dalam masa lebih akhir berwujud dalam bentuk negara-bangsa (Ridwan dan Muhadjirin, 2003: 69). Dengan demikian mengutip Von der Mehden, Islam secara sadar atau tidak didefenisikan sebagai simbol nasional. Secara teologis, Islam juga memungkinkan umatnya untuk menganut paham nasionalisme. Ungkapan "cinta tanah air adalah sebagian dari iman menjadi sangat mengakar dalam sanubari kalangan Islam sehingga qaul/perkataan ulama ini begitu terkenal sehingga menjadi prinsip yang selalu dikhotbahkan oleh para penganjur nasionalisme di Indonesia.

Berbeda dengan kedua pandangan terdahulu yang menunjukkan adanya kaitan yang erat antara agama dengan nasionalisme dengan mengambil contoh nasionalisme Indonesia, Abdus Salam (dalam Moesa, 2007: 318) dalam kajiannya justru menyimpulkan bahwa pada dasarnya nasionalis me bertentangan dengan ajaran Islam. Alasannya menurut Salam adalah : Pertama, watak dasar Islam adalah universal, sedangkan watak dasar nasionalisme adalah partikular. Oleh larena itu, Islam menyodorkan kepada manusia sistem kemasyarakatan yang adil dan luhur menuju terwujudnya negara-dunia (world state), bukan negara-bangsa (nation state) seperti yang dikehendaki oleh nasionalisme. Kedua, semangat nasionalisme seringkali berlebihan dalam $\mathrm{m}$ e $\mathrm{ngung} \mathrm{gu} 1 \mathrm{kan}$ ra s a 
kebangsaannya, padahal tidak ada nilai yang lebih unggul melebihi Islam, sebagaimana sabda Nabi : "Islam adalah tinggi dan tidak bisa diungguli oleh ajaran apapun". Ketiga, dalam nasionalisme terkandung potensi ekstrimisme yang destruktif dan memecah belah. Didirikannya PBB (Perserikatan Bangsa-Bangsa) adalah wujud nyata dari upaya meminimalisir dampak negatif dari nasionalisme.

Dari beberapa pendekatan yang digambarkan di atas, penulis belum menemukan hasil-hasil penelitian maupun buku - buku yang secara spesifik membahas pemaknaan nasionalisme dalam konteks komunitas lokal di perbatasan antar negara. Nampak bahwa kajian yang ada masih lebih fokus pada tataran konseptual teoritik tentang nasionalisme. Penelitian ini berusaha memahami dan mendeskripsikan bagaimana aspek internal dari manusia, seperti simbol-simbol, ide-ide, nilai-nilai tradisional dan sistem keyakinan atau system of belief (Moesa, 2007: xvi) menjadi faktor yang sangat dominan dalam konstruksi pemaknaan (meaning constuction) tentang nasionalisme masyarakat Sebatik. Makna-makna yang mereka pegangi tersebut kemudian diasumsikan sebagai hasil penafsiran mereka (Moesa, 2007: 8).

\section{METODE PENELITIAN}

Lokasi penelitian di Pulau Sebatik Kabupaten Nunukan Kalimantan Timur dengan pertimbangan, Pertama, Pulau Sebatik secara administratif terbagi dua, sebagian masuk dalam wilayah Indonesia, dan sebagian lagi masuk wilayah Malaysia. Kedua, dengan posisi tepat di titik perbatasan ini, maka diharapkan secara langsung dapat terlihat adanya kesenjangan kehidupan antara masyarakat Sebatik dengan masyarakat Malaysia. Ketiga, mata uang yang beredar ada dua, yakni ringgit dan rupiah. Keempat, proses asimilasi (pembauran) yang terjadi antar penduduk kedua negara relatif cair karena adanya persamaan suku dan kelima, sepanjang pengetahuan penulis, belum pernah ada penelitian tentang bagaimana pemaknaan nasionalisme masyarakat lokal di pulau Sebatik.

Metode yang digunakan untuk memperoleh data yang diperlukan, pertama, berupa observasi partisipasi yang merupakan metode pengumpulan data yang mengharuskan periset untuk terlibat langsung dalam kehidupan masyarakat. Periset harus dapat memahami gejala yang ada dalam masyarakat serta harus memahami maknanya sebagaimana yang diberikan atau dipahami oleh masyarakat yang sedang diteliti (Salim, 2006: 220). Observasi partisipasi dimaksudkan untuk mengamati secara langsung pola perilaku sosial masyarakat yang nantinya menjadi acuan dalam melakukan wawancara. Observasi partisipasi dilakukan pada masyarakat Pulau Sebatik yang dalam kehidupan sehari-hari sangat tergantung dengan Tawau-Malaysia.

Kedua, wawancara mendalam yang dimaksudkan untuk mendapatkan data melalui komunikasi langsung 
yang dilakukan beberapa kali agar didapat gambaran yang lengkap dan utuh tentang pandangan informan. Teknik ini bertujuan untuk memperoleh data yang dapat dipertanggungjawabkan. Adapun informan terdiri dari sejumlah tokoh masyarakat serta sejumlah masyarakat yang dianggap memiliki pemahaman terhadap masalah yang akan diteliti. Dalam metode ini, wawancara yang dilakukan tidak bersifat formal, tapi lebih pada wawancara informal yang sifatnya spontan, sehingga peneliti dapat mendapatkan data sesuai dengan masalah yang sedang diteliti. Karakter yang spontan tersebut menjadikan metode ini bersifat lebih obyektif dan sahih, sebab tidak ditemukan rekayasa yang dilakukan terlebih dahulu oleh peneliti (Salim, 2006: 223).

Ketiga, dokumentasi yang dimaksudkan untuk mendapatkan data melalui dokumen atau literatur yang erat kaitannya dengan masalah yang diteliti. Dokumentasi ini berupa buku, arsip, surat-surat, foto, dan catatan lainnya yang diharapkan bisa menjelaskan kondisi masyarakat Pulau Sebatik yang tinggal di wilayah perbatasan Indonesia-Malaysia.

Karena penelitian ini bersifat kualitatif yang sangat tergantung pada kemampuan observasi, wawancara, dan interpretasi, maka analisis yang digunakan adalah analisis data kualitatif model etnografi, yakni model penelitian yang lebih banyak terkait dengan antropologi dengan mempelajari peristiwa kultural, menyajikan pandangan hidup subyek yang menjadi obyek studi (Muhadjir, 2000). Tugas peneliti adalah mengoreknya keluar dari pikiran manusia (Spradley, 2007: xii). Dengan logika ini, maka paradigma analisis data penelitian ini mengacu pada metode grounded research oleh Schlegel (1984) yang intinya bahwa semua analisis harus didasarkan pada data yang ada dan bukan pada berbagai ide yang ditetapkan sebelumnya, sehingga hasil yang diperoleh sewaktuwaktu dapat berubah sesuai dengan data yang baru masuk.

Analisis data digunakan dengan melibatkan penafsiran langsung terhadap makna dan fungsi tindakan manusia. Dalam analisis ini dilakukan interpretasi berupa pemberian makna terhadap fakta sosial budaya yang ada melalui keterkaitan antara berbagai fenomena. Dengan cara ini diharapkan berbagai macam fenomena sosial budaya kaitannya dengan pemaknaan nasionalisme oleh masyarakat Pulau Sebatik di wilayah perbatasan Indonesia-Malaysia dapat dideskripsikan dengan jelas agar kualitas penelitian mendekati realitas empirik. Hasil analisis berbentuk deskripsi dan penjelasan verbal dengan menggunakan istilah-istilah dan makna-makna yang asli (native), disamping juga memakai istilah yang digunakan peneliti sendiri (etnografer).

\section{HASIL PENELITIAN DAN PEMBAHASAN}

Pada bagian ini akan diuraikan bagaimana pemaknaan nasionalisme masyarakat Pulau Sebatik dengan menggunakan indikator seperti pada Tabel 1 berikut : 
Tabel 1. Pemaknaan Nasionalisme dengan Beberapa Indikator

\begin{tabular}{|c|c|c|}
\hline \multirow[b]{2}{*}{ INDIKATOR } & \multicolumn{2}{|c|}{ KELOMPOK MASYARAKAT } \\
\hline & $\begin{array}{c}\text { Masyarakat yang hanya memiliki KTP } \\
\text { Indonesia atau } \\
\text { orang tempatan (I) }\end{array}$ & $\begin{array}{c}\text { Masyarakat yang memiliki KTP } \\
\text { Indonesia dan ID Card Malaysia atau } \\
\text { berkepala dua (II) }\end{array}$ \\
\hline KTP & $\begin{array}{l}\text { Tidak berusaha untuk menjadi warga } \\
\text { negara Malaysia meskipun sangat } \\
\text { tergantung secara ekonomi dengan alasan } \\
\text { bahwa Indonesia adalah harga mati. }\end{array}$ & $\begin{array}{l}\text { Dengan memiliki kewarganegaraan ganda, } \\
\text { dapat mempermudah akses di kedua } \\
\text { negara, baik ekonomi maupun kesehatan, } \\
\text { karena fasilitas yang ada di Malaysia lebih } \\
\text { baik. Meski demikian Indonesia tetap } \\
\text { menjadi pilihan ketika harus memilih. }\end{array}$ \\
\hline Mata Uang & $\begin{array}{l}\text { Lebih banyak menggunakan mata uang } \\
\text { ringgit sebagai alat tukar. Rupiah } \\
\text { hanya menjadi alat tukar alternatif }\end{array}$ & $\begin{array}{l}\text { Lebih banyak menggunkan mata uang } \\
\text { ringgit sebagai alat tukar. Rupiah hanya } \\
\text { menjadi alat tukar alternatif }\end{array}$ \\
\hline Ekonomi & $\begin{array}{l}\text { Aktifitas ekonomi sehari - hari sangat } \\
\text { tergantung pada Malaysia, dan lebih } \\
\text { banyak menggunakan barang - barang } \\
\text { produksi Malaysia. }\end{array}$ & $\begin{array}{l}\text { Aktifitas ekonomi sehari - hari sangat } \\
\text { tergantung pada Malaysia, dan lebih } \\
\text { banyak menggunakan barang - barang } \\
\text { produksi Malaysia. }\end{array}$ \\
\hline Bahasa & $\begin{array}{l}\text { Bahasa sehari - hari yang banyak digunakan } \\
\text { dalam berinteraksi adalah bahasa Bugis. }\end{array}$ & $\begin{array}{l}\text { Lebih banyak menggunakan bahasa Bugis } \\
\text { dalam interaksi sehari - hari, baik di Pulau } \\
\text { Sebatik maupun di Malaysia. }\end{array}$ \\
\hline Pendidikan & $\begin{array}{l}\text { Memilih menyekolahkan anak di } \\
\text { Indonesia, meskipun ada peluang di } \\
\text { Malaysia. Alasannya agar lebih mudah } \\
\text { mengawasi anak dan bisa membantu } \\
\text { pekerjaan orang tua sepulang sekolah, baik } \\
\text { itu di kebun, rumah dan lain - lain. }\end{array}$ & $\begin{array}{l}\text { Lebih memilih menyekolahkan anak di } \\
\text { Indonesia, meskipun peluang untuk } \\
\text { menyekolahkan anak di Malaysia terbuka } \\
\text { lebar dengan pertimbangan lebih sering di } \\
\text { Indonesia dari pada di Malaysia. Aktifitas } \\
\text { ke Malaysia hanya pada kondisi - kondisi } \\
\text { tertentu saja, misalnya berobat, berbelanja } \\
\text { dan kunjungan keluarga. }\end{array}$ \\
\hline $\begin{array}{l}\text { Partisipasi } \\
\text { Politik }\end{array}$ & $\begin{array}{l}\text { Berpartisipasi dalam setiap pemilu, } \\
\text { pilkada, dan pilkades sebagai wujud } \\
\text { tanggung jawab sebagai warga negara } \\
\text { Indonesia. }\end{array}$ & $\begin{array}{l}\text { Berpartisipasi dalam setiap pemilu, } \\
\text { pilkada, dan pilkades yang diadakan di } \\
\text { Indonesia serta berpartisipasi dalam pemilu } \\
\text { Malaysia. }\end{array}$ \\
\hline $\begin{array}{l}\text { Perayaan HUT } \\
\text { Kemerdekaan } \\
\text { RI }\end{array}$ & $\begin{array}{l}\text { Ikut terlibat dalam setiap perayaan HUT RI } \\
\text { dengan segala kegiatan dalam rangka } \\
\text { memeriahkan. }\end{array}$ & $\begin{array}{l}\text { Ikut terlibat dalam setiap perayaan HUT RI } \\
\text { dengan segala kegiatan dalam rangka } \\
\text { memeriahkan. }\end{array}$ \\
\hline Kasus Ambalat & $\begin{array}{l}\text { Jika terjadi perang saudara antara Indonesia } \\
\text { dengan Malaysia terkait konflik blok } \\
\text { Ambalat, menyatakan siap untuk mati } \\
\text { membela Indonesia }\end{array}$ & $\begin{array}{l}\text { Meskipun berkewarga negaraan ganda, } \\
\text { namun jika terjadi perang saudara antara } \\
\text { Indonesia dengan Malaysia, lebih memilih } \\
\text { membela Indonesia ketimbang Malaysia. }\end{array}$ \\
\hline
\end{tabular}

Sumber: Diolah Dari Data Primer

Tabel 1 di atas, menunjukkan bahwa terdapat enam indikator, yakni mata uang, ekonomi, bahasa, pendidikan, perayaan HUT Kemerdekaan RI, dan Kasus Ambalat yang memiliki kesamaan pemaknaan antara masyarakat yang hanya memiliki KTP Indonesia dengan masyarakat yang memiliki KTP Indonesia dan ID Card Malaysia. Hal ini disebabkan karena pada dasarnya kedua kelompok masyarakat ini lebih banyak berdomisili di Pulau Sebatik ketimbang Malaysia. Untuk dua indikator lainnya, yakni KTP dan partisipasi politik sangat berbeda diantara dua kelompok masyarakat karena masyarakat yang hanya memiliki KTP Indonesia sangat terbatas dalam mengakses segala 
sesuatu yang ada kaitannya dengan Malaysia, sedangkan masyarakat yang memiliki KTP Indonesia dan ID Card Malaysia bisa dengan mudah mengakses ke Malaysia, salah satu contoh, jika pemilu di Malaysia mereka turut berpartisipasi memberikan suara.

Pemaknaan nasionalisme masyarakat Pulau Sebatik sangat dipengaruhi oleh lingkungan internal dan eksternal. Lingkungan internal berupa interaksi dan relasi yang dilakukan sesama warga Indonesia dalam lingkup Pulau Sebatik, sedangkan lingkungan eksternal berupa interaksi dan relasi masyarakat Pulau Sebatik dengan warga negara Malaysia yang selama ini menjadi mitra dalam melakukan kegiatan, khususnya kegiatan ekonomi. Berikut ini akan digambarkan tentang pemaknaan nasionalisme masyarakat Pulau Sebatik dengan dua model berdasarkan beberapa indikator, seperti kepemilikan KTP, mata uang, ekonomi, bahasa, pendidikan, partisipasi politik, perayaan HUT kemerdekaan RI, dan kasus Ambalat (tabel 1).

\section{a. Model Pertama, Masyarakat Yang Hanya Memiliki KTP Indonesia (Orang Tempatan)}

Dari beberapa indikator yang ada, nampak dengan jelas bahwa masyarakat Pulau Sebatik dengan kelompok pertama ini meskipun dalam kehidupan sehari-hari secara ekonomi sangat tergantung pada Malaysia dan lebih senang menggunakan mata uang ringgit, namun bahasa sehari-hari yang digunakan untuk berinteraksi adalah bahasa Bugis. Itulah sebabnya mengapa tetap saja nasionalisme (rasa kebangsaan) sebagai orang Indonesia tetap terjaga dengan baik. Mungkin pepatah yang cocok untuk masyarakat kategori pertama ini adalah "hujan emas di negeri orang, hujan batu di negeri masih lebih baik negeri sendiri". Nasionalisme yang dimaknai oleh masyarakat kelompok ini adalah selalu merasa sebagai orang Indonesia di manapun berada. Menariknya, justru ada warga yang sejak tinggal di Pulau Sebatik tidak pernah sama sekali menginjakkan kaki ke Tawau, padahal jaraknya cukup dekat.

Meskipun demikian, sebenarnya tidak semua masyarakat memiliki pandangan yang sama tentang Malaysia. Di antara sekian banyak masyarakat yang menjadikan Malaysia sebagai tempat untuk memburu rezeki, ternyata masih ada segelintir orang yang justru tidak berminat dengan berbagai alasan. Hal ini dipengaruhi oleh lingkungan internal dan eksternal seperti yang disebutkan di atas. Kasus warga Pulau Sebatik yang tidak berminat ke Malaysia memburu ringgit sangat dipengaruhi oleh faktor eksternal, dimana tidak adanya pengalaman mereka melakukan relasi dengan warga Malaysia, sehingga keinginan untuk melakukan hal-hal seperti yang dilakukan oleh mayoritas masyarakat Pulau Sebatik di Malaysia tidak ada.

Dalam hal pendidikan, masyarakat dengan kelompok pertama ini, bagi yang sudah menetap di Pulau Sebatik lebih 
memilih menyekolahkan anak di Indonesia mulai dari tingkat TK sampai SMU dengan alasan selepas sekolah dapat membantu pekerjaan mereka. Selain itu, mereka dengan mudah dapat mengontrol perkembangan pendidikan anakanak mereka jika bersekolah di pulau Sebatik meskipun ada peluang untuk bisa menyekolahkan anak-anak mereka di Malaysia.

Terkait dengan partisipasi politik, masyarakat dengan kelompok pertama ini pada dasarnya memiliki kesadaran untuk ikut berpartisipasi dalam setiap perhelatan politik seperti kampanye, diskusi politik, pemilu, dan pilkada yang diadakan di Pulau Sebatik. Hal ini mereka lakukan sebagai bentuk kesadaran akan pentingnya proses politik yang ada terhadap masa depan bangsa, meskipun kadang tokoh-tokoh politik yang ada selama ini lebih banyak memberikan janji-janji untuk melakukan perbaikanperbaikan bagi pulau Sebatik, khususnya pada saat kampanye pemilu maupun pilkada, namun kenyataannya jauh panggang dari api. Masyarakat dengan model ini terdiri atas dua kelompok, yakni yang bermukim di Pulau Sebatik dan yang bermukim di TawauMalaysia tetapi tetap sebagai warga Pulau Sebatik karena hanya memiliki KTP Indonesia.

Tinggi-rendahnya partisipasi politik masyarakat di Pulau Sebatik sangat dipengaruhi oleh apa yang dikemukakan oleh Ramlan Surbakti (2007: 144), bahwa ada dua faktor yang mempengaruhi tinggi rendahnya partisipasi politik seseorang, yaitu kesadaran politik dan kepercayaan kepada pemerintah. Untuk mengetahui tinggi rendahnya partisipasi politik warga masyarakat Pulau Sebatik, maka pendapat Paige tentang partisipasi penting sebagai bahan acuan. Berdasarkan tinggi rendahnya kedua faktor di atas, Paige (dalam Surbakti, 2007: 144), membagi partisipasi ke dalam empat tipe. Pertama, apabila seseorang memiliki kesadaran politik dan kepercayaan kepada pemerintah tinggi, maka partisipasi politik cenderung aktif.

Kedua, apabila kesadaran politik dan kepercayaan kepada pemerintah rendah, maka partisipasi politik cenderung pasiftertekan (apatis). Ketiga, tipe partisipasi militan radikal, dimana apabila kesadaran politik tinggi, tapi kepercayaan kepada pemerintah sangat rendah. Keempat, apabila kesadaran politik sangat rendah , tapi kepercayaan kepada pemerintah sangat tinggi, maka partispasi ini disebut tidak aktif(pasif).

Mengacu pada keempat tipe partisipasi yang dikemukakan oleh Paige di atas, dalam konteks masyarakat Pulau Sebatik menurut hemat penulis, lebih mengarah pada tipe yang kedua, yakni kesadaran politik dan kepercayaan kepada pemerintah rendah. Kasus di Pulau Sebatik menunjukkan adanya hubungan sebab akibat, dimana rendahnya tingkat kesadaran politik 
warga diakibatkan oleh adanya ketidakpercayaan warga kepada pemerintah akibat rendahna komitmen pemerintah dalam mengelola wilayah perbatasan.

Terkait dengan perayaaan HUT Kemerdekaan RI, masyarakat kelompok pertama ini atau yang biasa disebut orang tempatan sama seperti masyarakat di wilayah lain, mereka sangat antusias meramaikan kegiatan-kegiatan yang diadakan sebagai rangkaian dari HUT RI tersebut. Pertandingan olah raga misalnya, tidak pernah sepi penonton. Hal yang sama juga terjadi pada perlombaan seni yang diminati oleh seluruh lapisan masyarakat. Dengan suka cita mereka memanfaatkan momen perayaan HUT kemerdekaan RI sebagai sarana untuk mempererat kebersamaan serta memupuk rasa kebangsaan yang hanya setiap tahun bisa mereka rasakan. Selain itu, perayaan HUT Kemerdekaan RI juga wahana untuk memperkuat rasa kebangsaan ditengah kuatnya ketergantungan hidup kepada Malaysia. Perasaan senasib dan sepenanggungan sebagai masyarakat pinggiran Indonesia menjadi kekuatan tersendiri dalam menghadapi setiap tantangan yang selama ini memang akrab dengan kehidupan mereka. Meskipun sering diperlakukan tidak adil oleh penguasa negeri ini, misalnya infrastruktur yang masih terbatas dan tidak kunjung ditingkatkan kualitasnya, padahal sangat dibutuhkan oleh masyarakat untuk memudahkan akses perekonomian yang menunjang peningkatan kesejahteraan, namun mereka tetap menunjukkan rasa nasionalisme dengan cara mereka sendiri melalui HUT Kemerdekaan RI.

Selain itu, bukti masih terjaganya rasa kebangsaan masyarakat Pulau Sebatik dari masyarakat kelompok pertama dapat dilihat pada kasus sengketa antara Indonesia-Malaysia di perairan blok Ambalat yang sampai saat ini dipersengketakan dan masih dalam proses diplomasi. Mereka menyatakan siap untuk mati jika memang benar-benar terjadi perang, meskipun mereka berkeyakinan bahwa perang saudara antara Indonesia dengan Malaysia sangat sulit untuk terjadi sekarang ini karena kedua negara sudah saling membutuhkan satu sama lain. Di satu sisi, Malaysia membutuhkan orang-orang Indonesia sebagai tenaga keraja dalam sektor pertanian, di sisi lain Indonesia membutuhkan Malaysia sebagai tempat para TKI mencari sesuap nasi. Namun jika benarbenar terjadi membela Indonesia adalah taruhan.

b. Model Kedua : Masyarakat Yang Memiliki KTP Indonesia dan ID Card Malaysia (Berkepala Dua)

Dari beberapa indikator yang ada, masyarakat dengan model kedua ini memiliki banyak kesamaan dengan masyarakat model pertama. Meskipun orientasi mereka berbeda dalam hal kepemilikan kartu identitas (KTP), namun indikator yang lain menunjukkan kecenderungan yang sama. Mereka memiliki kartu 
identitas ganda pada dasarnya bertujuan untuk memudahkan akses di kedua negara, khususnya akses ekonomi dan kesehatan. Di Malaysia sudah jelas fasilitas kesehatan sangat memadai dibandingkan di Indonesia. Namun demikian, jika harus memilih, masyarakat model kedua ini tetap akan memilih Indonesia.

Adanya warga berkartu identitas ganda (berkepala dua) yang dikeluarkan oleh dua negara berbeda, jika diselami lebih jauh merupakan imbas dari tidak terpenuhinya social rights ${ }^{2}$ masyarakat Pulau Sebatik yang pada akhirnya menggantungkan kehidupan ekonominya kepada Malaysia. Berkepala dua adalah pilihan yang dilematis. Di satu sisi, sebagai warga negara yang berada di perbatasan, mereka dituntut untuk senantiasa memperkuat rasa kebangsaan, namun di sisi lain, mereka juga harus berusaha untuk tetap survive ditengah ketertinggalan ekonomi, sosial bahkan politik. Inilah sebuah paradoks yang menjadi realita dalam masyarakat perbatasan di Pulau Sebatik.

Dalam hal penggunaan mata uang ringgit, masyarakat dengan model kedua ini sama dengan model pertama yang sangat tengantung pada peredaran ringgit. Seperti yang telah dijelaskan pada bab II tulisan ini bahwa ringgit sebagai alat tukar utama karena segala kebutuhan pokok warga Pulau Sebatik merupakan barang produk Malaysia yang secara otomatis diperdagangkan dengan ringgit. Hukum pasar inilah yang menyebabkan monopoli ringgit tetap langgeng. Selain itu, sama seperti model pertama, alasan lain lebih memilih ringgit karena nilai ringgit yang tinggi ketimbang rupiah.

Untuk aktifitas ekonomi sehari-hari, sama seperti orang tempatan, orang berkepala dua ini sangat tergantung pada barangbarang kebutuhan pokok dari Malaysia karena barang kebutuhan pokok Indonesia sangat jarang diperdagangkan. Salah seorang warga yang berkepala dua ini, seperti pengamatan penulis memiliki usaha toko obat yang mayoritas obatnya didatangkan dari Malaysia serta memiliki kebun kelapa sawit yang sudah dikelola sendiri. Jika ingin menambah stok obat, warga ini menyeberang ke Malaysia untuk berbelanja dan tidak mendapatkan kesulitan apa-apa karena dalam berbelanja menggunakan ID Card Malaysia. Jika warga Indonesia yang tidak memiliki ID Card Malaysia ketahuan membawa obat-obatan ke Indonesia, maka itu termasuk penyelundupan dan sudah pasti melanggar aturan. Inilah gambaran sederhana keuntungan yang dimiliki oleh mereka yang berkepala dua dibandingkan orang tempatan.

${ }^{2}$ Sicia Rights terdiri atas hak-hak mendapatkan kesejahteraan dan keamanan ekonomi dan hak untuk mendapatkan bagian yang layak dalam kesejahteraan sosial dan hidup sebagai seorang yang beradab menurut standar masyarakat di mana individu itu hidup. (Marshall, 1992). 
Untuk penggunaan bahasa sehari-hari, masyarakat model kedua ini juga menggunakan bahasa Bugis, baik ketika berada di Pulau Sebatik maupun ketika berada di Malaysia. Hal ini dimungkinkan karena interaksi yang dilakukan lebih banyak dengan relasi yang juga etnis Bugis. Kuatnya penggunaan bahasa Bugis ini secara langsung memberi pengaruh yang signifikan bagi terjaganya rasa kebangsaan mereka di sela-sela pergaulan dengan lingkungan yang berbeda, apakah itu di Pulau Sebatik maupun di Malaysia.

Dalam hal pendidikan, masyarakat model kedua ini sama seperti model pertama lebih memilih menyekolahkan anak di Indonesia dengan alasan mudah mengontrol anak, meski kesempatan menuntut di Malaysia cukup terbuka. Alasan lain adalah bahwa sekolah dasar dan menengah di Indonesia lumayan bagus sehingga wajar kalau masyarakat menyekolahkan anaknya di Pulau Sebatik.

Mengenai partisipasi politik, masyarakat model kedua ini memiliki kesamaan dengan model yang pertama, dimana dalam setiap perhelatan politik yang diadakan di Pulau Sebatik masyarakat ikut berpartisipasi sebagai wujud kepedulian terhadap peristiwa politik yang terjadi. Hanya saja yang berbeda adalah ketika pemilu di Malaysia, mereka juga ikut berpartisipasi untuk ikut pemilu yang merupakan konsekuensi sebagai warga negara Malaysia.

Dalam perayaan HUT Kemerdekaan RI, masyarakat model kedua ini sama dengan model pertama. Keterlibatan cukup aktif dalam kegiatan yang diadakan sebagai rangkaian perayaan. Dalam pertandingan olah raga dan lombalomba misalnya, mereka cukup memberikan andil. Berbeda pada saat perayaan HUT Kemerdekaan Malaysia, mereka tidak terlibat secara aktif, paling jauh mereka hanya sebagai partisan yang pasif sebagai penonton dalam setiap kegiatan yang diadakan di Malaysia.

Saat terjadi sengketa blok Ambalat antara IndonesiaMalaysia, dan isu akan terjadi perang saudara begitu kuat di media-media Indonesia, masyarakat model kedua ini sama seperti model pertama menyatakan siap untuk membela Indonesia kalau benar-benar terjadi perang. Meskipun bagi mereka Malaysia adalah tempat mencari kehidupan serta memperoleh kemudahan dan keuntungan, namun persoalan berjuang membela negara Indonesia adalah sebuah kewajiban. Indonesia tetap tanah tumpah darah yang mesti di bela dan diperjuangkan ketika mendapat ancaman dari negara lain.

c. Model Ketiga : Masyarakat Yang Telah Menjadi Warga Negara Malaysia (Orang Malaysia yang Cinta Indonesia)

Seperti yang dikemukakan di awal bab ini, penulis hanya akan 
menggambarkan bagaimana orang Indonesia yang telah menjadi warga negara Malaysia dalam merefleksikan nasionalisme. Sebagai bukti bahwa mereka masih memiliki jiwa nasionalisme terhadap Indonesia, biasanya masyarakat dengan model ini untuk menunjukkan rasa kebangsaannya membuka usaha lahan kelapa sawit di Pulau Sebatik, kemudian menyerahkan pengelolaannya kepada kerabat yang ada di Sebatik. Mereka hanya sesekali datang ke Pulau Sebatik mengontrol usaha. Ini adalah upaya konkrit dari seorang warga Indonesia yang telah menjadi warga negara Malaysia untuk membantu perekonomian saudarasaudara mereka di Indonesia sebagai bentuk tanggung jawab moral dan partisipasi bagi peningkatan kesejahteraan masyarakat pinggiran di perbatasan. Mereka memang warga negara Malaysia, tapi tetap cinta Indonesia yang diwujudkan dengan turut andil dalam membantu saudara-saudara mereka di Indonesia.

Ada yang terpaksa menjadi warga negara Malaysia demi untuk masa depan anak-anak mereka. Pengalaman bekerja di Malaysia dan melihat perbedaan kehidupan di Indonesia dengan Malaysia telah mengubah pandangan mereka dengan satu harapan dapat mengubah nasib ketika menjadi warga negara Malaysia. Meskipun telah menjadi warga negara Malaysia, mereka tetap menjaga hubungan kekeluargaan dengan kerabat yang ada di Sulawesi Selatan.
Dari ketiga model masyarakat yang telah diuraikan di atas, dapat disimpulkan bahwa pemaknaan nasionalisme masyarakat Pulau Sebatik yang diwujudkan dalam berbagai hal yang dapat dilihat dari beberapa indikator di atas. Pada akhirnya, apa yang dikuatirkan oleh beberapa kalangan tentang lunturnya jiwa nasionalisme masyarakat di perbatasan, ternyata tidak sepenuhnya benar dalam kasus masyarakat Pulau Sebatik. Realitas yang ada bahwa meskipun sangat tergantung secara ekonomi pada Malaysia, rasa kebangsaan atau nasionalisme masyarakat masih tetap terjaga dengan baik. Hal ini dibuktikan dari fakta-fakta yang diuraikan berdasarkan indikatorindikator yang ada.

\section{E. KESIMPULAN}

Mengacu pada paparan fakta empiris yang muncul dalam penelitian ini, dapat ditarik benang merah bahwa untuk mengkaji nasionalisme (rasa kebangsaan) masyarakat yang ada di Pulau Sebatik dapat dilihat dengan beberapa indikator, yakni KTP, mata uang, ekonomi, bahasa, pendidikan, partisipasi politik, perayaan HUT Kemerdekaan RI, dan kasus Ambalat. Terdapat dua kelompok masyarakat yang memberikan pemaknaan nasionalisme berdasarkan indikator tersebut yaitu masyarakat yang memiliki KTP Indonesia (orang tempatan) dan masyarakat yang memiliki KTP Indonesia dan ID Card Malaysia (berkepala dua). 
Kedua kelompok masyarakat ini memberikan konstruksi nasionalisme dengan tindakantindakan yang menunjukkan rasa ke-Indonesiaan yang tetap terpelihara, meskipun banyak dipengaruhi oleh hal-hal yang berbau Malaysia seperti yang tergambar dalam tabel 1, sedangkan kelompok ketiga merefleksikan rasa ke-Indonesiaan dengan melakukan kegiatan-kegiatan di pulau Sebatik dengan tujuan agar setiap saat dapat menginjakkan kaki ke Pulau Sebatik sekaligus membantu kerabat sebagai wujud tanggung jawab dan empati atas kondisi yang dialami oleh kerabat mereka.

Dari gambaran yang telah diuraikan, dapat dikatakan bahwa pada hakekatnya pemaknaan nasionalisme dari ketiga kelompok masyarakat tersebut sangat sederhana. Nasionalisme menurut mereka tidak lebih dari rasa yang senantiasa terpatri dalam jiwa sebagai bangsa Indonesia, di manapun dan dalam kondisi apapun. Malaysia bagi mereka hanya sebagai ladang untuk mencari penghidupan yang lebih layak yang belum mereka raih di Indonesia.

\section{DAFTAR PUSTAKA}

Abubakar, M., 2006, Menata PulauPulau Kecil Perbatasan: Belajar dari Kasus Sipadan, Ligitan, dan Sebatik, Jakarta: PT. Kompas Media Nusantara.

Anderson, B., 1999, Imagined
Communities: Komunitaskomunitas Imajiner: Renungan Tentang Asal Usul dan Penyebaran Nasionalisme (terj. Omi Intan Naomi), Yogyakarta: Insist Press \& Pustaka Pelajar.

Hamdanah, 2005, Musim Kawin di Musim Kemarau : Studi atas Pandangan Ulama Perempuan Jember Tentang Hak-Hak Reproduksi Perempuan, Yogyakarta: B I GR A F Publishing.

Hara, E., 2005, Nasionalisme Indonesia: Dari Nasionalisme Lokal ke Nasionalisme Kosmopolit, Politika Vol. 1, No. 2.

Kartodirdjo, S., 1999, Multidimensi Pembangunan Bangsa: Etos Nasionalisme dan Negara Kesatuan, Yogyakarta: Kanisius.

Legawa, N., 2007, Nasionalisme Postkolonial (Studi Tentang Pengaruh Kolonialisme terhadap Tumbuhnya Identitas $N$ asional Indonesia Postkolonial), Skripsi.

Mas'oed, M., 2000, "Nasionalisme dan Tantangan Global Masa Kini" dalam Ichlasul Amal dan Armaidy Armawi (ed). Regionalisme, Nasionalisme, dan Ketahanan Nasional, Yogyakarta: Gadjah Mada Press.

Moesa, A.M., 2007, Nasionalisme Kiai: Konstruksi Sosial 
Berbasis Agama, Yogyakarta: LKIS.

Monigue, K.R., 1967, Nationalism, London: Methuen.

Nasution, M.A., 2001, Orang Indonesia di Malaysia: Menjual Kemiskinan Membangun Identitas, Yogyakarta: Pustaka Pelajar.

Purwanto, B., 2001, Memahami Kembali Nasionalisme Indonesia, Ilmu Sosial dan Ilmu Politik Vol. 4 No. 3.

Ratnawati, T., 2006. Potret Pemerintahan Lokal Di Indonesia Dimasa Perubahan: Otonomi Daerah Tahun 20002005, Yogyakarta: Pustaka Pelajar dan P2P LIPI.

Rauf, M., 2008, "Mengubah Karakter Bangsa Warisan Orde Baru", dalam Refleksi Karakter Bangsa, Jakarta: Forum Kajian Antripologi Indonesia.

Saifuddin, A.F., M. Karim, 2008, "Memperbincangkan Kembali Karakter Bangsa", dalam Refleksi Karakter Bangsa, Jakarta: Forum Kajian Antropologi Indonesia.

Santoso, P., 2001, Merajut Kohesi Nasional: Etno-nasionalisme dan Otonomi Daerah dalam Proses Demokratisasi, Ilmu Sosial dan Ilmu Politik Vol. 4 No. 3.

Surbakti, R., 2007, Memahami Ilmu
Politik, Jakarta: Gramedia Widiasarana Indonesia.

Tjondronegoro, S (ed.), 2007, Membangun Negara dan Mengembangkan Demokras", Yogyakarta: Aditya Media bekerja sama dengan Komisi Ilmu-ilmu Sosial Akademi Ilmu Pengetahuan Indonesia (AIPI).

Zakaria, R., 2006, Hegel dan Nasionalisme: Dinamika dan Perkembangan, Governance Vol. 2 No. 6.

\section{Media Massa}

Kompas, 17 Pebruari 2009 